\title{
Expression of PD-L1 in triple-negative breast cancer based on different immunohistochemical antibodies
}

Woo Young Sun ${ }^{1}$, Yu Kyung Lee ${ }^{2}$ and Ja Seung Koo ${ }^{2^{*}}$

\begin{abstract}
Background: To date, there are no effective therapeutic targeting agents for triple-negative breast cancer (TNBC), and PD-L1 has presented potential as an effective marker of immunotherapeutic agents. The aim of this study was to evaluate the expression of PD-L1 by three different immunohistochemical antibodies in TNBC.

Methods: Interpretation of all three PD-L1 antibodies showed good concordance among three readers (kappa value $>0.610$ ) in both cancer cells and immune cells. Using a tissue microarray (TMA) constructed from 218 cases of TNBC, we performed immunohistochemical staining using three of the most popular commercially used PD-L1 monoclonal antibodies (clones 28-8, E1 L3N and SP142) in cancer cells and immune cells.

Results: Using various cut-off values of previous studies $(1,5,10$ and $50 \%)$, the expression rates in cancer cells were: PD-L1 (E1L3N) (14.7, 14.7, 11.0, 2.3 \%), PD-L1 (28-8) (13.3, 12.4, 10.1, 1.8 \%), and PD-L1 (SP142) (11.5, 11.0, 6.9, 0.5 \%), respectively. At the $5 \%$ cut-off value, the discordance rate among the three antibodies was $6.0-10.6 \%$ and was highest between PD-L1 (SP142) and the other two antibodies. The expression rates in immune cells were PD-L1 (E1L3N) (37.6\%), PD-L1 (28-8) (36.7\%), and PD-L1 (SP142) (19.3\%), and the discordance rate among the three antibodies ranged from 13.8 to $24.8 \%$ and was also highest between PD-L1 (SP142) and the other two antibodies. Among stromal histologic types, higher PD-L1 expression in cancer cells and immune cells was measured in inflammatory-type $(p<0.05)$. The absence of PD-L1 (28-8) staining in immune cells was associated with shorter disease free survival (DFS) and overall survival (OS) $(p=0.043$, and $p=0.021)$ in univariate analyses, and with shorter OS in multivariate Cox analysis (hazard ratio: $5.429,95 \% \mathrm{Cl} 1.214-24.28, \mathrm{p}=0.027$ ).

Conclusions: PD-L1 detection in cancer cells and immune cells varied by antibody clone. The greatest amount of staining occurred with PD-L1 (E1L3N), followed by PD-L1 (28-8) and PD-L1 (SP142). The concordance rate among monoclonal PD-L1 antibodies was higher between PD-L1 (28-8) and PD-L1 (E1L3N). To determine the gold standard antibody and the most appropriate cut-off value, further study of the clinical trial group treated with PD-L1 inhibitor is necessary.
\end{abstract}

Keywords: Breast cancer, PD-L1, Monoclonal antibody, Immunohistochemistry, Triple negative

\section{Background}

Breast cancer is a heterogeneous disease that has several clinical, histological, and genetic forms. There have been many attempts to categorize this heterogeneous disease,

\footnotetext{
*Correspondence: kjs1976@yuhs.ac

2 Department of Pathology, Yonsei University College of Medicine, Severance Hospital, 50 Yonsei-ro, Seodaemun-gu, Seoul 120-752, South Korea

Full list of author information is available at the end of the article
}

and now molecular classification into five groups (luminal A, luminal B, HER-2, normal breast-like, and basallike) can be accomplished by gene-expression profiling $[1,2]$.

Among these molecular subtypes, basal-like breast cancer has a more aggressive clinical course than other subtypes and is commonly known as triple-negative breast cancer (TNBC), which is defined clinically as lacking estrogen receptor (ER) and progesterone receptor 
(PR) and human epidermal growth factor receptor 2 (HER2). TNBC accounts for $10-17 \%$ of all breast cancers [3-8]. Highly heterogeneous and known to have several molecular subtypes, TNBC is difficult to treat because it does not respond to hormonal or targeted therapy such as Herceptin, except chemotherapy [9-11].

Programmed death 1 (PD-1) is a check point molecule in immune reactions and can be expressed in various immune cells [12]. PD-L1, a ligand of PD-1, is expressed in cancer cells and the binding of PD-L1 with PD-1 helps cancer cells avoid antitumor immune responses [13, 14]. PD-L1 expression has been reported at rates of $20-70 \%$ in lung cancer [13, 15-18], urinary bladder cancer [19], malignant melanoma [20], and ovarian cancer [21]. PD-L1 was expressed in not only tumor cells but immune cells in previous studies of breast cancer [22-24], and lung cancer [25]. In addition, its expression in immune cells demonstrated clinical implication [23]. Therefore, the evaluation of PD-L1 should be performed in both cancer cell and immune cells.

Target therapy for PD-L1 in PD-L1-expressing cancers represents a possible treatment for inducing antitumor immune responses. PD-L1-targeted therapy has been investigated in preclinical and clinical trials in many tumors [15-17, 19, 26-28] and anti-PD-L1 antibodies such as BMS-936,559 [29] and MPDL3280A [16, 19] have been developed. Knowledge of the expression of PD-L1 in cancer cells plays an important role in tailored therapy planning, and is easily evaluated using immunohistochemistry (IHC) with a monoclonal PD-L1 antibody in formalin-fixed and paraffin-embedded (FFPE) specimens. Multiple monoclonal PD-L1 antibodies such clone 28-8 [30], clone 22C3 [31], clone SP142 [16, 19], and clone E1L3N [32,33] have been commercially developed.

The aim of this study was to evaluate the expression of PD-L1 using different immunohistochemical antibodies in TNBC and associated clinical implications.

\section{Methods \\ Patient selection}

We analyzed 218 patients with TNBC who underwent surgery at Severance Hospital between January 2000 and December 2006. This study was approved by the Institutional Review Board of Severance Hospital. All patients were diagnosed as having invasive ductal carcinoma, not otherwise specified (NOS) by pathologists. We defined TNBC as when IHC for ER, PR, and HER-2 and FISH for HER-2 were all negative.

ER and PR immunohistochemistry signal were considered positive when more than $1 \%$ of invasive tumor cells were expressed [34]. HER-2 staining was scored according to the American Society of Clinical Oncology (ASCO)/ College of American Pathologists (CAP) guideline using the following categories: 0 , no immunostaining; $1+$, weak incomplete membranous staining in any proportion of tumor cells; $2+$, complete membranous staining, either non uniform or weak in at least $10 \%$ of tumor cells; and $3+$, uniform intense membranous staining in $>30 \%$ of tumor cells [35]. Cases with 0 to $1+$ were regarded as negative and case with $3+$ was considered as positive. Cases with HER-2 2+ were investigated with FISH (Vysis pathvision HER-2 kit) for HER-2 gene status. As proposed by the ASCO/CAP guideline, an absolute HER-2 gene copy number lower than four or HER-2 gene/chromosome 17 copy number ratio (HER-2/Chr17 ratio) of less than 1.8 was considered HER-2 negative; an absolute HER-2 copy number between 4 and 6 or HER-2/Chr17 ratio between 1.8 and 2.2 was considered HER-2 equivocal; and an absolute HER2 copy number greater than 6 or HER-2/Chr17 ratio higher than 2.2 was considered HER-2 positive.

Formalin-fixed and paraffin-embedded tissue specimens from 218 cases of primary breast cancer were included. All archival hematoxylin and eosin (H\&E)stained slides for each case were reviewed by one pathologists (Koo JS). The histological grade was accessed using Nottingham grading system [36]. According to the microscopic cancer stoma findings, TNBC was categorized as follows [37]: desmoplastic type, with cellular fibroblast/myofibroblast proliferation as the main stromal content; sclerotic type, which has a small cell component and fibrotic collagenous component as its main stromal content; or inflammatory type, with stroma mainly composed of inflammatory cells such as lymphocytes. Tumor staging was based on the 8th American Joint Committee on Cancer (AJCC) criteria. Disease-free survival (DFS) time was measured from the date of the first curative surgery to the date of the first locoregional or systemic relapse, or death without any type of relapse. Overall survival (OS) time was calculated from the date of the first curative operation to the date of the last follow-up or death from any cause. Histologic parameters were evaluated from the $\mathrm{H} \& \mathrm{E}$-stained slides. Clinical parameters evaluated in each tumor included patient age at initial diagnosis, lymph node status, local recurrence, systemic recurrence, and patient's survival.

\section{Tissue microarray}

On H\&E-stained slides of tumors, a representative area was selected and a corresponding spot was marked on the surface of the paraffin block. Using a punch machine, the selected area was punched out and a $3-\mathrm{mm}$ tissue core was placed into a $6 \times 5$ recipient block. More than two tissue cores were extracted to minimize extraction bias. Each tissue core was assigned with a unique tissue microarray location number that was linked to a database containing other clinicopathologic data. 


\section{Immunohistochemistry (IHC)}

The antibodies and dilution used for IHC are shown in Additional file 1: Table S1. All immunohistochemistry was performed with formalin-fixed, paraffin-embedded tissue sections using an automatic immunohistochemistry staining device (Benchmark XT, Ventana Medical System, Tucson, AZ, USA). Briefly, 5- $\mu$ m-thick formaldehyde fixed paraffin-embedded tissue sections were transferred onto adhesive slides and dried at $62{ }^{\circ} \mathrm{C}$ for $30 \mathrm{~min}$. Standard heat epitope retrieval was performed for $30 \mathrm{~min}$ in ethylene diamine tetraacetic acid, $\mathrm{pH}$ 8.0, in the autostainer. The samples were then incubated with primary antibodies. After incubation with primary antibodies, The sections were subsequently incubated with biotinylated anti-mouse immunoglobulins, peroxidaselabeled streptavidin (LSAB kit, DakoCytomation), and 3,30-diaminobenzidine. Negative control samples were processed without the primary antibody. Slides were counterstained with Harris hematoxylin. Positive control tissue was used as per the manufacturer's recommendation (placenta and tonsil). Slides were counterstained with Harris hematoxylin. Optimal primary antibody incubation times and concentrations were determined by serial dilution for each immunohistochemical assay using a tissue block fixed and embedded exactly as for the experiments.

\section{Interpretation of immunohistochemical staining}

We evaluated the expression of immunohistochemical markers in cancer cells and peri-tumoral immune cells by light microscopy. Expression in cancer cells was analyzed by various cut-off values $(1,5,10$ and $50 \%)$ and expression in immune cells was analyzed as follows: negative, no immunostaining; low-positive, stained immune cells $\leq 30 /$ high power field (HPF); and high-positive, stained immune cells $>30 / \mathrm{HPF}$.

Interpretation of immunohistochemical staining was performed independently by three researchers (SWY, LYK, KJS). We investigated the proportion of expression (\%) in cancer cells according to the above criteria, counted the number of expressed immune cells. Each of three pathologists analyzed the samples and reached a conclusion, which were then analyzed to determine inter-reader concordance. The final results were determined through discussion and multi-view microscopy in the cases that showed discrepancy among the three pathologists.

\section{Statistical analysis}

Data were analyzed using SPSS for Windows, Version 12.0 (SPSS Inc., Chicago, IL, USA). For determination of statistical significance, Student's $t$ and Fisher's exact tests were used for continuous and categorical variables, respectively. The inter-reader concordance rate and concordance rate among PD-L1 antibodies were analyzed using the Kappa-Cohen method. Statistical significance was when $\mathrm{p}<0.05$. Kaplan-Meier survival curves and log-rank statistics were employed to evaluate time to tumor recurrence and overall survival. Multivariate regression analysis was performed using Cox proportional hazards model.

\section{Results}

\section{Basal characteristics of TNBC}

Among the 218 TNBC patients, a desmoplastic type was observed in 138 cases (63.3\%), inflammatory type in 63 cases (28.9\%), and sclerotic type in 17 cases (7.8\%). There was no difference in clinicopathologic factors according to stromal type (Additional file 1: Table S2).

\section{Inter-reader reproducibility for monoclonal PD-L1 antibodies}

The kappa values of all three PD-L1 antibodies were $>0.610$ in both cancer cells and immune cells. In cancer cells, the concordance rate was highest when using a $1 \%$ cut-off value, while the lowest concordance rate was seen at the $10 \%$ cut-off value (Table 1 ).

\section{PD-L1 monoclonal antibody staining in TNBC cells and immune cells}

Among the different PD-L1 monoclonal antibodies, PD-L1 (E1L3N) showed the highest expression rate in cancer cells (14.7, 14.7, 11.0, $2.3 \%)$ and immune cells (37.6 \%) and PD-L1 (SP142) showed the lowest expression rate in cancer cells $(11.5,11.0,6.9,0.5 \%)$ and immune cells $(19.3 \%)$ for all cut-off values $(1,5,10$, and $50 \%$ ) (Table 2; Fig. 1). The kappa value between PD-L1 (28-8) and PD-L1 (E1L3N) was higher than those between PD-L1 (28-8) and PD-L1 (SP142) and between PD-L1 (SP142) and PD-L1 (E1L3N) in both cancer cells and immune cells. Therefore, the concordance rate among monoclonal PD-L1 antibodies was higher between PD-L1 (28-8) and PD-L1 (E1L3N) (Table 3).

At the $5 \%$ cut-off value, the discordance rate between PD-L1 (28-8) and PD-L1 (E1L3N) was $6 \%$ (13 cases) and was higher in PD-L1 (28-8)-negative/PD-L1 (E1L3N)positive (9 cases) than PD-L1 (28-8)-positive/PD-L1 (E1L3N)-negative (4 cases) cells. The discordance rate between PD-L1 (28-8) and PD-L1 (SP142) was $10.6 \%$ (23 cases) and was higher in PD-L1 (28-8)-positive/PD-L1 (SP142)-negative (13 cases) than PD-L1 (28-8)-negative/ PD-L1 (SP142)-positive (10 cases) cells. Likewise, discordance was higher in PD-L1 (E1L3N)-positive/PD-L1 (SP142)-negative (15 cases) than PD-L1 (E1L3N)-negative/PD-L1 (SP142)-positive (7 cases) cells (Additional file 1: Table S3). 
Table 1 Kappa value for inter-reader reproducibility of PD-L1 monoclonal antibodies

\begin{tabular}{|c|c|c|c|c|c|c|c|c|c|c|c|c|c|c|c|}
\hline \multirow[t]{3}{*}{ Reader } & \multicolumn{5}{|c|}{ PD-L1 (28-8) } & \multicolumn{5}{|c|}{ PD-L1 (E1L3N) } & \multicolumn{5}{|c|}{ PD-L1 (SP142) } \\
\hline & \multicolumn{4}{|c|}{ Tumor cell } & \multirow{2}{*}{$\begin{array}{l}\text { Immune } \\
\text { cell }\end{array}$} & \multicolumn{4}{|c|}{ Tumor cell } & \multirow{2}{*}{$\begin{array}{l}\text { Immune } \\
\text { cell }\end{array}$} & \multicolumn{4}{|c|}{ Tumor cell } & \multirow{2}{*}{$\begin{array}{l}\text { Immune } \\
\text { cell }\end{array}$} \\
\hline & $1 \%$ & $5 \%$ & $10 \%$ & $50 \%$ & & $1 \%$ & $5 \%$ & $10 \%$ & $50 \%$ & & $1 \%$ & $5 \%$ & $10 \%$ & $50 \%$ & \\
\hline \#1 to \#2 & 1.000 & 0.913 & 0.770 & 0.838 & 0.903 & 1.000 & 0.943 & 0.876 & 0.887 & 0.914 & 1.000 & 0.871 & 0.889 & 1.000 & 0.928 \\
\hline \#1 to \#3 & 1.000 & 0.958 & 0.923 & 0.838 & 0.894 & 1.000 & 0.981 & 0.820 & 0.887 & 0.888 & 1.000 & 0.976 & 0.924 & 1.000 & 0.858 \\
\hline \#2 to \#3 & 1.000 & 0.913 & 0.794 & 0.628 & 0.798 & 1.000 & 0.923 & 0.670 & 1.000 & 0.870 & 0.977 & 0.842 & 0.803 & 1.000 & 0.788 \\
\hline
\end{tabular}

Table 2 Expression of PD-L1 monoclonal antibodies in TNBC

\begin{tabular}{|c|c|c|c|}
\hline Parameters & PD-L1 (28-8) & PD-L1 (E1L3N) & PD-L1 (SP142) \\
\hline \multicolumn{4}{|c|}{ Cancer cell compartment } \\
\hline \multicolumn{4}{|c|}{$1 \%$ cut-off value } \\
\hline Negative & $189(86.7)$ & $186(85.3)$ & $193(88.5)$ \\
\hline Positive & $29(13.3)$ & $32(14.7)$ & $25(11.5)$ \\
\hline \multicolumn{4}{|l|}{$5 \%$ cut-off value } \\
\hline Negative & $191(87.6)$ & $186(85.3)$ & $194(89.0)$ \\
\hline Positive & $27(12.4)$ & $32(14.7)$ & $24(11.0)$ \\
\hline \multicolumn{4}{|c|}{$10 \%$ cut-off value } \\
\hline Negative & $196(89.9)$ & $194(89.0)$ & $203(93.1)$ \\
\hline Positive & $22(10.1)$ & $24(11.0)$ & $15(6.9)$ \\
\hline \multicolumn{4}{|l|}{$50 \%$ cut-off value } \\
\hline Negative & $214(98.2)$ & $213(97.7)$ & $217(99.5)$ \\
\hline Positive & $4(1.8)$ & $5(2.3)$ & $1(0.5)$ \\
\hline \multicolumn{4}{|c|}{ Immune cell compartment } \\
\hline Negative & $138(63.3)$ & $136(62.4)$ & $176(80.7)$ \\
\hline Low positive & $59(27.1)$ & $55(25.2)$ & $40(18.3)$ \\
\hline High positive & $21(9.6)$ & $27(12.4)$ & $2(0.9)$ \\
\hline
\end{tabular}

In immune cells, PD-L1 (E1L3N) had the highest and PD-L1 (SP 142) had the lowest total positive expression rate. The low-positive rate was higher with PD-L1 (28-8) than PD-L1 (E1L3N); however, the high-positive rate was higher with PD-L1 (E1L3N) than PD-L1 (288). In the analysis for expression concordance among the three antibodies in immune cells, the discordance rate between PD-L1 (28-8) and PD-L1 (E1L3N) was $13.8 \%$ (30 cases), with 14 PD-L1 (28-8)-positive/PD-L1 (E1L3N)-negative cases and 16 PD-L1 (28-8)-negative/PD-L1 (E1L3N)-positive cases. The discordance rate between PD-L1 (28-8) and PD-L1 (SP142) was $24.8 \%$ (54 cases), with 46 PD-L1 (28-8)-positive/PD-L1 (SP142)-negative cases and 8 PD-L1 (28-8)-negative/ PD-L1 (SP142)-positive cases. Finally, the discordance rate between PD-L1 (E1L3N) and PD-L1 (SP142) was $22.0 \%$ (48 cases), with 44 PD-L1 (E1L3N)-positive/ PD-L1 (SP142)-negative cases and 4 PD-L1 (E1L3N)negative/PD-L1 (SP142)-positive cases (Additional file 1: Table S4).
Correlation of PD-L1 expression between cancer cells and immune cells

The concordance rate between cancer cells and immune cells was higher for PD-L1 (28-8) ( $<<0.001)$. For PD-L1 (SP142), the concordance rate was higher for positive staining in cancer cells and in negative staining in immune cells $(\mathrm{p}<0.001$, Table 4$)$.

\section{Correlation between PD-L1 expression and clinicopathologic factors}

Correlation in cancer cells was analyzed using a $5 \%$ cutoff value, as in most previous studies. Among the stromal histologic types, inflammatory-type cancer cells and immune cells had the highest PD-L1 expression $(\mathrm{p}<0.05$, Fig. 2). Lymph node metastasis correlated with PD-L1 (28-8) negativity in cancer cells $(\mathrm{p}=0.002)$, while higher Ki-67 LI correlated with PD-L1 (28-8) positivity and PD-L1 (E1L3N) positivity in immune cells ( $\mathrm{p}=0.010$ and $\mathrm{p}=0.001$, respectively) (Fig. 3).

\section{Impact of expression of PD-L1 on patient prognosis in TNBC}

In univariate analysis, PD-L1 (28-8) negativity in immune cells was associated with shorter disease-free survival (DFS) and overall survival (OS) $(\mathrm{p}=0.043$, and $\mathrm{p}=0.021$, Table 6; Fig. 4). In multivariate Cox analysis, factors related to shorter DFS included higher T stage (hazard ratio: 10.21, $95 \%$ CI 1.306-79.90, p $=0.027$ ) and lymph node metastasis (hazard ratio: 3.918, 95 \% CI 1.254-12.24, $\mathrm{p}=0.019$ ), while factors related to shorter OS were higher $\mathrm{T}$ stage (hazard ratio: $6.317,95 \% \mathrm{CI}$ 1.413-28.23, $\mathrm{p}=0.016$ ), lymph node metastasis (hazard ratio: 3.564, $95 \%$ CI 1.304-9.740, $\mathrm{p}=0.013$ ), and PD-L1 (28-8) negativity in immune cells (hazard ratio: 5.112, $95 \%$ CI 1.110-23.54, $\mathrm{p}=0.036$, Table 7).

\section{Discussion}

This study sought to evaluate the immunohistochemical expression of PD-L1 using several monoclonal antibodies in TNBC. We performed IHC under the same conditions with different antibody clones and found differences in PD-L1 expression in both tumor cells and immune cells (Table 7). 


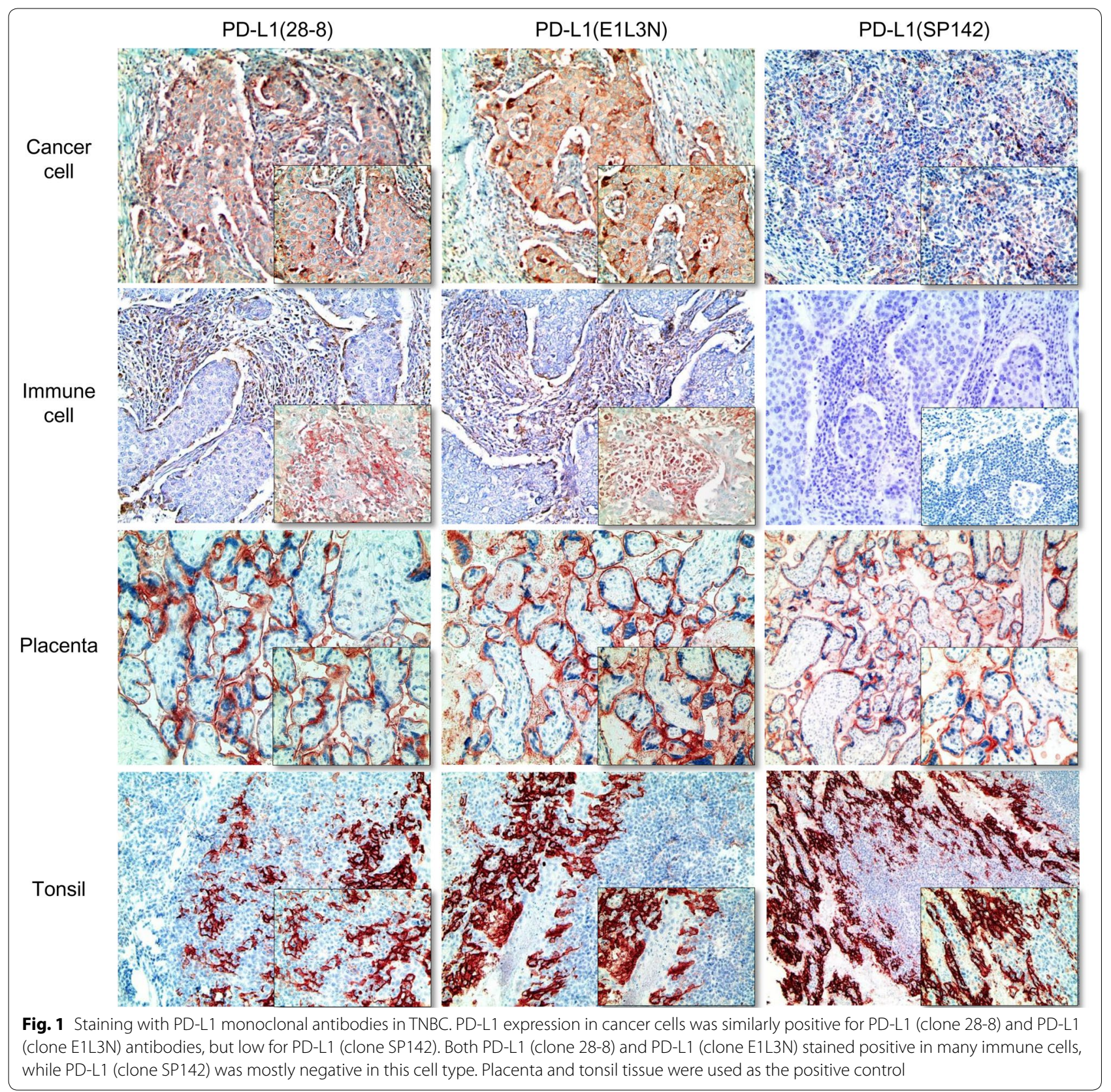

Table 3 Kappa value for inter-PD-L1 antibodies concordance

\begin{tabular}{|c|c|c|c|c|c|}
\hline \multirow[t]{2}{*}{ Antibody } & \multicolumn{4}{|l|}{ Tumor cell } & \multirow[t]{2}{*}{ Immune cell } \\
\hline & $1 \%$ cut-off & $5 \%$ cut-off & $10 \%$ cut-off & $50 \%$ cut-off & \\
\hline PD-L1 (28-8) to PD-L1 (E1L3N) & 0.752 & 0.745 & 0.660 & 0.887 & 0.607 \\
\hline PD-L1 (28-8) to PD-L1 (SP142) & 0.535 & 0.490 & 0.558 & 0.396 & 0.309 \\
\hline PD-L1 (SP142) to PD-L1 (E1L3N) & 0.537 & 0.551 & 0.580 & 0.328 & 0.305 \\
\hline
\end{tabular}


Table 4 Correlation of expression of PD-L1 between cancer cell and immune cell

\begin{tabular}{|c|c|c|c|}
\hline & \multicolumn{2}{|c|}{ PD-L1 (28-8) in cancer cell } & \multirow[t]{2}{*}{$p$ value } \\
\hline & Negative & Positive & \\
\hline PD-L1 (28-8) in immune cell & & & $<0.001$ \\
\hline Negative & $130(68.1)$ & $8(29.6)$ & \\
\hline \multirow[t]{3}{*}{ Positive } & $61(31.9)$ & $19(70.4)$ & \\
\hline & \multicolumn{2}{|c|}{$\begin{array}{l}\text { PD-L1 (E1L3N) in cancer } \\
\text { cell }\end{array}$} & $\mathrm{p}$ value \\
\hline & Negative & Positive & \\
\hline PD-L1 (E1L3N) in immune cell & & & 0.117 \\
\hline Negative & $120(64.5)$ & $16(50.0)$ & \\
\hline \multirow[t]{3}{*}{ Positive } & $66(35.5)$ & $16(50.0)$ & \\
\hline & \multicolumn{2}{|c|}{$\begin{array}{l}\text { PD-L1 (SP142) in cancer } \\
\text { cell }\end{array}$} & p value \\
\hline & Negative & Positive & \\
\hline PD-L1 (SP142) in immune cell & & & $<0.001$ \\
\hline Negative & $163(84.0)$ & $13(54.2)$ & \\
\hline Positive & $31(16.0)$ & $11(45.8)$ & \\
\hline
\end{tabular}

The high concordance rate among the three readers in the interpretation of PD-L1 yielded acceptable interreader reproducibility with a kappa value $>0.610$ in both cancer cells and immune cells. Especially in cancer cells, the concordance rate was highest at a $1 \%$ cut-off value and lowest at a $10 \%$ cut-off value. This is likely because the reader tends to interpret as positive in $1 \%$ cut-off even in slight expression and increase concordance rate, and tends to have more likely subjective interpretation in $10 \%$ cut-off value. However, improvement in the response rate from $35 \%$ at a $1 \%$ cut-off value to $44 \%$ at a $5 \%$ cut-off value was seen in a nivolumab phase I study targeting malignant melanoma, indicating that the higher $5 \%$ cut-off value was more reasonable [38]. Therefore, further response-based studies of TNBC are necessary.

Variation in PD-L1 expression rates previously observed in a study of various cancers has been attributed to differences in cut-off values, antibodies, and study populations $[39,40]$, and this phenomenon is also commonly seen with other antibodies [41]. In lung cancer characterized with PD-L1 expression, expression rates varied from 24 to $60 \%$ using the same $5 \%$ cut-off value $[15,16,42]$, and from 21 to $95 \%$ according to different cut-off values of 1,10 and $50 \%[13,17,18,43]$.

PD-L1 expression in TNBC was present at $19 \%$ (clone $5 \mathrm{H} 1$ with a $5 \%$ cut-off) [44] and $64-80 \%$ (clone E1L3N, with a $1 \%$ cut-off) [45] in previous studies. In our study, the expression rate was $11.5-14.7 \%$ with a $1 \%$ cut-off value and $11.0-14.7 \%$ with a $5 \%$ cut-off value, which was similar to the previous report of $19 \%$. We presume that differences in expression rate are due primarily to different characteristics of the PD-L1 antibody clones, because all samples were stained using the same immunohistochemical conditions.

PD-L1 showed membranous expression in this study, in agreement with one previous study in TNBC [44], but the other TNBC study reported both cytoplasmic and membranous expression of PD-L1 [45]. PD-L1 expression has been reported in the cell membrane [17, 26-28] or membrane and cytoplasm $[13,16,18]$ in other cancers. We performed IHC using an automatic IHC staining device, but the previous research in TNBC that evaluated cytoplasm expression had no clear description of staining, making it difficult to compare our findings directly with previous data [45]. We found expression of PD-L1 in 19.3-37.6 \% of cancer cells and immune cells, depending on the antibody clone. Although our expression rate was different than a previous study with $93 \%$ immune cell expression in TNBC, it was in concordance with the previous report in terms of positive immune cell expression [45]. PD-L1 expression in immune cells has been reported in other cancers [16, 19, 25, 28]. There are differences between oncogene-driven PD-L1 expression and inflammation-driven PD-L1 expression. While oncogene-driven PD-L1 expression is constitutive and diffuse, inflammation-driven PD-L1 expression is limited to sites of IFN $\gamma$-mediated immunologic attack [46]. In addition, inflammation-driven PD-L1 expression is related to immune infiltrates, while oncogene-driven PD-L1 expression is not $[28,47]$. Thus, further study to know which expression between two expressions is more related to the expression of PD-L1 on immune cell in TNBC.

In this study, the concordance rate between PD-L1 (288) and PD-L1 (E1L3N) was high in both cancer cells and immune cells while PD-L1 (SP142) showed low concordance rates with the other two antibodies. Previous studies reported poor concordance (kappa value: 0.124-0.340) between PD-L1 (E1L3N) and PD-L1 (SP142) in lung cancer [48], but a high concordance rate between PD-L1 (E1L3N) and PD-L1 (SP142) (more than $85 \%$ ) in malignant melanoma [49]. Therefore, concordance seems to vary according to cancer type; further study on this topic is needed.

PD-L1 positivity in immune cells (28-8 clone) was an independent prognostic factor in our study, in contrast to previous studies showing good prognosis [50-53] or poor prognosis $[54,55]$ with PD-L1 expression in cancer cells. Since the prognostic and predictive significance of PD-L1 expression in immune cells such as macrophages and lymphocytes was not associated with tumor-related PD-L1 expression [16], further study of the biologic implications of PD-L1 in immune cells during TNBC is needed. 


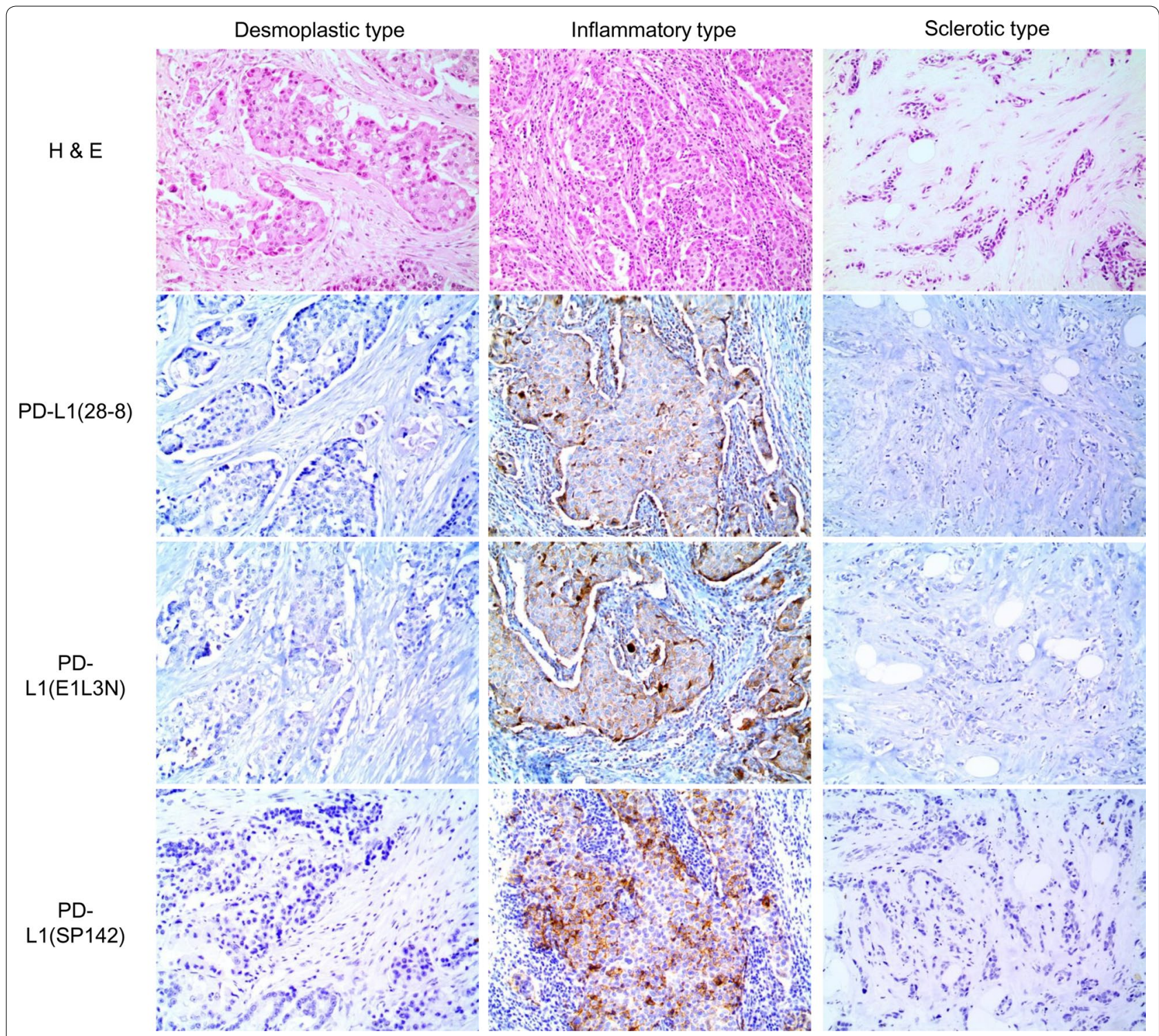

Fig. 2 Staining with PD-L1 monoclonal antibodies according to stromal histologic type. Staining of cancer cells and surrounding immune cells using different three antibodies was higher in inflammatory type cells (Table 5)
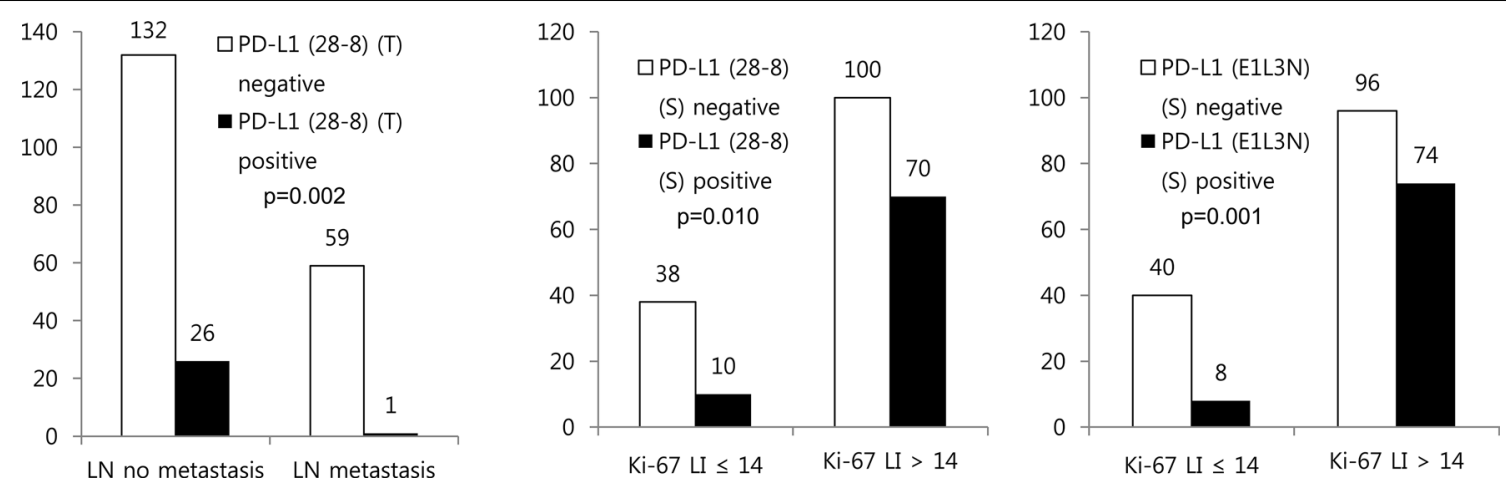

Fig. 3 Correlation of expression of PD-L1 and clinicopathologic factors in TNBC 
Table 5 PD-L1 expression according to the stromal types in triple negative breast cancer

\begin{tabular}{|c|c|c|c|c|c|}
\hline \multirow[t]{2}{*}{ Parameters } & \multirow{2}{*}{$\begin{array}{l}\text { Total } \\
\mathrm{N}=\mathbf{2 1 8}(\%)\end{array}$} & \multicolumn{3}{|l|}{ Stromal type } & \multirow[t]{2}{*}{$p$ value } \\
\hline & & $\begin{array}{l}\text { Desmoplastic } \\
n=138(\%)\end{array}$ & $\begin{array}{l}\text { Inflammatory } \\
n=63(\%)\end{array}$ & $\begin{array}{l}\text { Sclerotic } \\
n=17(\%)\end{array}$ & \\
\hline PD-L1 (28-8) (T) & & & & & 0.005 \\
\hline Negative & $191(87.6)$ & $127(92.0)$ & $48(76.2)$ & $16(94.1)$ & \\
\hline Positive & $27(12.4)$ & $11(8.0)$ & 15 (23.8) & $1(5.9)$ & \\
\hline PD-L1 (E1L3N) (T) & & & & & $<0.001$ \\
\hline Negative & $186(85.3)$ & $126(91.3)$ & $44(69.8)$ & $16(94.1)$ & \\
\hline Positive & $32(14.7)$ & $12(8.7)$ & $19(30.2)$ & $1(5.9)$ & \\
\hline PD-L1 (SP142) (T) & & & & & 0.001 \\
\hline Negative & $194(89.0)$ & $130(94.2)$ & $48(76.2)$ & $16(94.1)$ & \\
\hline Positive & $24(11.0)$ & $8(5.8)$ & 15 (23.8) & $1(5.9)$ & \\
\hline PD-L1 (28-8) (I) & & & & & $<0.001$ \\
\hline Negative & $138(63.3)$ & $100(72.5)$ & 25 (39.7) & $13(76.5)$ & \\
\hline Positive & $80(36.7)$ & $38(27.5)$ & $38(60.3)$ & $4(23.5)$ & \\
\hline PD-L1 (E1L3N) (I) & & & & & $<0.001$ \\
\hline Negative & $136(62.4)$ & $103(74.6)$ & $20(31.7)$ & $13(76.5)$ & \\
\hline Positive & $82(37.6)$ & 35 (25.4) & $43(68.3)$ & $4(23.5)$ & \\
\hline PD-L1 (SP142) (I) & & & & & $<0.001$ \\
\hline Negative & $176(80.7)$ & $121(87.7)$ & $40(63.5)$ & 15 (88.2) & \\
\hline Positive & $42(19.3)$ & $17(12.3)$ & $23(36.5)$ & $2(11.8)$ & \\
\hline
\end{tabular}

$T$ tumor cell, I immune cell

Table 6 Impact of expression of PD-L1 on disease-free and overall survival tested by log-rank analysis

\begin{tabular}{|c|c|c|c|c|c|}
\hline \multirow[t]{2}{*}{ Parameters } & \multirow{2}{*}{$\begin{array}{l}\text { Number of patients / } \\
\text { recurrence/death }\end{array}$} & \multicolumn{2}{|c|}{ Disease-free survival } & \multicolumn{2}{|l|}{ Overall survival } \\
\hline & & $\begin{array}{l}\text { Mean survival } \\
(95 \% \mathrm{Cl}) \text { months }\end{array}$ & $p$ value & $\begin{array}{l}\text { Mean survival } \\
(95 \% \mathrm{Cl}) \text { months }\end{array}$ & $p$ value \\
\hline PD-L1 (28-8) (T) & & & $\mathrm{N} / \mathrm{A}$ & & 0.967 \\
\hline Negative & 191/16/17 & N/A & & $91(87-95)$ & \\
\hline Positive & $27 / 0 / 2$ & N/A & & $59(54-64)$ & \\
\hline PD-L1 (E1L3N) (T) & & & $\mathrm{N} / \mathrm{A}$ & & 0.647 \\
\hline Negative & 186/16/17 & N/A & & $90(86-95)$ & \\
\hline Positive & $32 / 0 / 2$ & N/A & & $91(84-98)$ & \\
\hline PD-L1 (28-8) (I) & & & 0.043 & & 0.021 \\
\hline Negative & $138 / 14 / 17$ & 89 (84-93) & & $87(82-92)$ & \\
\hline Positive & $80 / 2 / 2$ & $97(94-100)$ & & $97(94-100)$ & \\
\hline PD-L1 (E1L3N) (I) & & & 0.761 & & 0.255 \\
\hline Negative & $136 / 11 / 15$ & $91(87-95)$ & & $88(84-93)$ & \\
\hline Positive & $82 / 5 / 4$ & $94(89-98)$ & & 95 (90-99) & \\
\hline PD-L1 (SP142) (I) & & & 0.191 & & 0.387 \\
\hline Negative & $176 / 15 / 17$ & 90 (86-94) & & $89(85-93)$ & \\
\hline Positive & $42 / 1 / 2$ & $97(93-101)$ & & 95 (89-100) & \\
\hline
\end{tabular}

Italics represents $\mathrm{p}<0.05$

$T$ tumor cell, I immune cell

In breast cancer, tumor infiltrating lymphocytes (TILs) have been linked with good prognosis [56], as have stromal TIL [57]. Therefore, tumor immunity may relate to prognosis in TNBC. PD-L1 expression was significantly higher in inflammatory type cancer cells and immune cells with all tested antibodies. Therefore, we assume that 

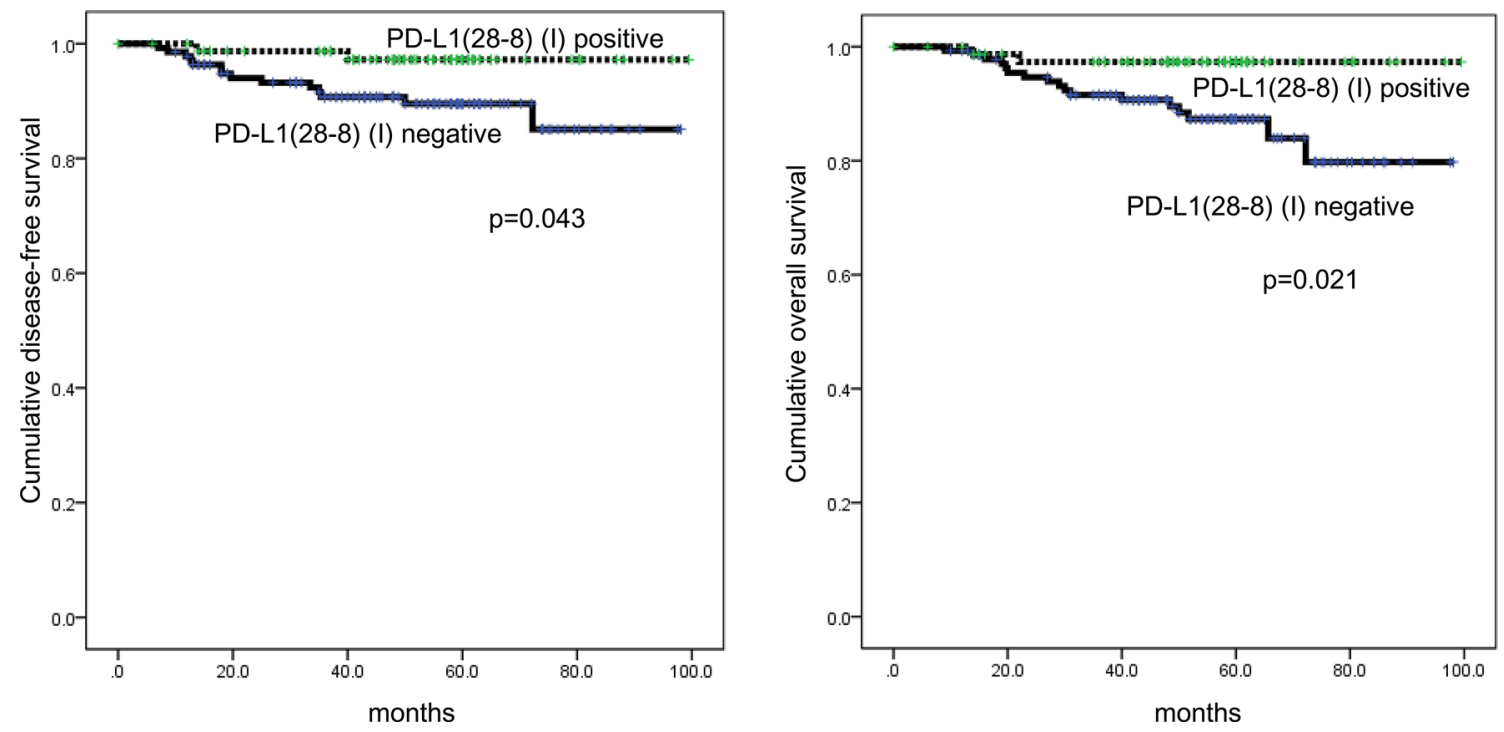

Fig. 4 Disease-free survival and overall survival according to PD-L1 (28-8) staining in immune cells

Table 7 Multivariate analysis of triple negative breast cancer survival

\begin{tabular}{|c|c|c|c|c|c|c|}
\hline \multirow[t]{2}{*}{ Included parameters } & \multicolumn{3}{|c|}{ Disease-free survival } & \multicolumn{3}{|c|}{ Overall survival } \\
\hline & Hazard ratio & $95 \% \mathrm{Cl}$ & p value & Hazard ratio & $95 \% \mathrm{Cl}$ & $\mathrm{p}$ value \\
\hline Histologic grade & & & 0.560 & & & 0.204 \\
\hline I/II versus III & 0.725 & $0.246-2.136$ & & 0.537 & $0.206-1.402$ & \\
\hline Tstage & & & 0.027 & & & 0.016 \\
\hline $\mathrm{T} 1$ versus $\mathrm{T} 2 / \mathrm{T} 3$ & 10.21 & $1.306-79.90$ & & 6.317 & $1.413-28.23$ & \\
\hline Lymph node metastasis & & & 0.019 & & & 0.013 \\
\hline No versus Yes & 3.918 & $1.254-12.24$ & & 3.564 & $1.304-9.740$ & \\
\hline Ki-67 LI & & & 0.327 & & & 0.711 \\
\hline$\leq 14$ versus $>14$ & 0.581 & $0.197-1.719$ & & 1.209 & $0.443-3.298$ & \\
\hline Stromal type & & & 0.988 & & & 0.699 \\
\hline Desmoplastic/sclerotic versus inflammatory & 0.990 & $0.266-19.15$ & & 1.287 & $0.359-4.613$ & \\
\hline PD-L1 (28-8) (I) & & & 0.081 & & & 0.036 \\
\hline Negative versus positive & 4.019 & $0.843-19.15$ & & 5.112 & $1.110-23.54$ & \\
\hline
\end{tabular}

Italics represents $\mathrm{p}<0.05$

I immune cell

PD-L1 expression in stromal immune cells is related to prognosis, and further research is needed to better elucidate this relationship.

Clinical trials targeting PD-L1 are underway [17, 58-60] and good responses have been reported [61, 62]. In TNBC, which has no effective therapy, PD-L1-targeting agents may play an important role and strong biomarkers that can predict treatment response are needed. Accordingly, staining of PD-L1 monoclonal antibodies may act as a biomarker for PD-L1-targeting agents, but clinical trials evaluating TNBC response to $\mathrm{PD}$-L1-targeting agents using monoclonal antibody staining will be needed to validate this strategy.
The limitation of this study was the potential difference in results between TMA and the whole cancer tissue section. Breast cancer also shows intracancer heterogeneity, like other types of cancer, and the expression of PD-L1 may cause differences between TMA and the whole cancer tissue section. PD-L1 expression in lung cancer showed a high discordance rate between TMA samples and whole tissue sections [48]. In a previous study, the results of immunohistochemical staining of ER in breast cancer were different in $5.5 \%$ between TMA and the whole cancer tissue section. Furthermore, when the number of cores was greater than one, this difference 
decreased to $1.4 \%$ [63]. In this study, two core extractions per case were performed to reduce this bias.

\section{Conclusions}

In conclusion, staining with PD-L1 (clone 28-8), PD-L1 (clone E1L3N), and PD-L1 (clone SP142) monoclonal antibodies in cancer cells and immune cells varied, with the highest staining by PD-L1 (E1L3N) and the lowest by PD-L1 (SP142). The concordance rate among monoclonal PD-L1 antibodies was higher between PD-L1 (28-8) and PD-L1 (E1L3N). PD-L1 positivity in immune cells correlated with a favorable prognosis. To determine the gold standard antibody and the most appropriate cut-off value, further study of the clinical trial group treated with $\mathrm{PD}-\mathrm{L} 1$ inhibitor is necessary.

\section{Additional file}

Additional file 1. Additional Tables, Tables S1-S4.

\begin{abstract}
Abbreviations
TNBC: triple-negative breast cancer; ER: estrogen receptor; PR: progesterone receptor; HER2: human epidermal growth factor receptor 2; PD: programmed death; PD-L: programmed death ligand; IHC: immunohistochemistry; FFPE: formalin-fixed and paraffin-embedded; NOS: not otherwise specified; ASCO: American Society of Clinical Oncology; CAP: College of American Pathologists; H\&E: hematoxylin and eosin; AJCC: American Joint Committee on Cancer; DFS: disease-free survival; OS: overall survival; HPF: high power field.
\end{abstract}

\section{Authors' contributions}

WYS participated in the design of the study and performed the statistical analysis and carried out the immunoassays. YL participated in its design. JSK conceived the study, and participated in its design and coordination and helped to draft the manuscript. All authors read and approved the final manuscript.

\section{Author details}

${ }_{1}^{1}$ Department of Surgery, Daejeon St. Mary's Hospital, The Catholic University of Korea College of Medicine, Seoul, South Korea. ${ }^{2}$ Department of Pathology, Yonsei University College of Medicine, Severance Hospital, 50 Yonsei-ro, Seodaemun-gu, Seoul 120-752, South Korea.

\section{Competing interests}

The authors declare that they have no competing interests.

\section{Ethics approval and consent to participate}

This study was approved by the Institutional Review Board (IRB) of Yonsei University Severance Hospital. Informed consent from patients was exempted by IRB.

\section{Funding}

This study was supported by a Grant from the National R\&D Program for Cancer Control, Ministry of Health \& Welfare, Republic of Korea (1420080). This research was supported by Basic Science Research Program through the National Research Foundation of Korea (NRF) funded by the Ministry of Science, ICT and Future Planning (2015R1A1A1A05001209).

Received: 22 February 2016 Accepted: 30 May 2016

Published online: 10 June 2016
References

1. Perou CM, Sorlie T, Eisen MB, van de Rijn M, Jeffrey SS, Rees CA, Pollack JR, Ross DT, Johnsen H, Akslen LA, Fluge O, Pergamenschikov A, Williams C, Zhu SX, Lonning PE, Borresen-Dale AL, Brown PO, Botstein D. Molecular portraits of human breast tumours. Nature. 2000;406:747-52.

2. Sorlie T, Perou CM, Tibshirani R, Aas T, Geisler S, Johnsen H, Hastie T, Eisen $M B$, van de Rijn M, Jeffrey SS, Thorsen T, Quist H, Matese JC, Brown PO, Botstein D, Eystein Lonning P, Borresen-Dale AL. Gene expression patterns of breast carcinomas distinguish tumor subclasses with clinical implications. Proc Natl Acad Sci USA. 2001;98:10869-74.

3. Bauer KR, Brown M, Cress RD, Parise CA, Caggiano V. Descriptive analysis of estrogen receptor (ER)-negative, progesterone receptor (PR)-negative, and HER2-negative invasive breast cancer, the so-called triple-negative phenotype: a population-based study from the California cancer Registry. Cancer. 2007;109:1721-8.

4. Carey LA, Dees EC, Sawyer L, Gatti L, Moore DT, Collichio F, Ollila DW, Sartor Cl, Graham ML, Perou CM. The triple negative paradox: primary tumor chemosensitivity of breast cancer subtypes. Clin Cancer Res. 2007;13:2329-34.

5. Dent R, Trudeau M, Pritchard KI, Hanna WM, Kahn HK, Sawka CA, Lickley $L A$, Rawlinson E, Sun P, Narod SA. Triple-negative breast cancer: clinical features and patterns of recurrence. Clin Cancer Res. 2007;13:4429-34.

6. Haffty BG, Yang Q, Reiss M, Kearney T, Higgins SA, Weidhaas J, Harris L, Hait W, Toppmeyer D. Locoregional relapse and distant metastasis in conservatively managed triple negative early-stage breast cancer. J Clin Oncol. 2006;24:5652-7.

7. Harris LN, Broadwater G, Lin NU, Miron A, Schnitt SJ, Cowan D, Lara J, Bleiweiss I, Berry D, Ellis M, Hayes DF, Winer EP, Dressler L. Molecular subtypes of breast cancer in relation to paclitaxel response and outcomes in women with metastatic disease: results from CALGB 9342. Breast Cancer Res. 2006;8:R66.

8. Rakha EA, Elsheikh SE, Aleskandarany MA, Habashi HO, Green AR, Powe DG, El-Sayed ME, Benhasouna A, Brunet JS, Akslen LA, Evans AJ, Blamey R, Reis-Filho JS, Foulkes WD, Ellis IO. Triple-negative breast cancer: distinguishing between basal and nonbasal subtypes. Clin Cancer Res. 2009;15:2302-10.

9. Lehmann BD, Bauer JA, Chen X, Sanders ME, Chakravarthy AB, Shyr Y, Pietenpol JA. Identification of human triple-negative breast cancer subtypes and preclinical models for selection of targeted therapies. J Clin Invest. 2011;121:2750-67.

10. Masuda H, Baggerly KA, Wang Y, Zhang Y, Gonzalez-Angulo AM, MericBernstam F, Valero V, Lehmann BD, Pietenpol JA, Hortobagyi GN, Symmans WF, Ueno NT. Differential response to neoadjuvant chemotherapy among 7 triple-negative breast cancer molecular subtypes. Clin Cancer Res. 2013;19:5533-40.

11. Prat A, Adamo B, Cheang MC, Anders CK, Carey LA, Perou CM. Molecular characterization of basal-like and non-basal-like triple-negative breast cancer. Oncologist. 2013;18:123-33.

12. Keir ME, Liang SC, Guleria I, Latchman YE, Qipo A, Albacker LA, Koulmanda M, Freeman GJ, Sayegh MH, Sharpe AH. Tissue expression of PD-L1 mediates peripheral T cell tolerance. J Exp Med. 2006;203:883-95.

13. Dong H, Strome SE, Salomao DR, Tamura H, Hirano F, Flies DB, Roche PC, Lu J, Zhu G, Tamada K, Lennon VA, Celis E, Chen L. Tumor-associated B7-H1 promotes T-cell apoptosis: a potential mechanism of immune evasion. Nat Med. 2002;8:793-800.

14. Brown JA, Dorfman DM, Ma FR, Sullivan EL, Munoz O, Wood CR, Greenfield EA, Freeman GJ. Blockade of programmed death-1 ligands on dendritic cells enhances T cell activation and cytokine production. J Immunol. 2003;170:1257-66.

15. D'Incecco A, Andreozzi M, Ludovini V, Rossi E, Capodanno A, Landi L, Tibaldi C, Minuti G, Salvini J, Coppi E, Chella A, Fontanini G, Filice ME, Tornillo L, Incensati RM, Sani S, Crino L, Terracciano L, Cappuzzo F. PD-1 and PD-L1 expression in molecularly selected non-small-cell lung cancer patients. Br J Cancer. 2015;112:95-102. 
16. Herbst RS, Soria JC, Kowanetz M, Fine GD, Hamid O, Gordon MS, Sosman JA, McDermott DF, Powderly JD, Gettinger SN, Kohrt HE, Horn L, Lawrence DP, Rost S, Leabman M, Xiao Y, Mokatrin A, Koeppen H, Hegde PS, Mellman I, Chen DS, Hodi FS. Predictive correlates of response to the anti-PD-L1 antibody MPDL3280A in cancer patients. Nature. 2014;515:563-7.

17. Garon EB, Rizvi NA, Hui R, Leighl N, Balmanoukian AS, Eder JP, Patnaik A, Aggarwal C, Gubens M, Horn L, Carcereny E, Ahn MJ, Felip E, Lee JS, Hellmann MD, Hamid O, Goldman JW, Soria JC, Dolled-Filhart M, Rutledge RZ, Zhang J, Lunceford JK, Rangwala R, Lubiniecki GM, Roach C, Emancipator K, Gandhi L. Pembrolizumab for the treatment of non-small-cell lung cancer. N Engl J Med. 2015;372:2018-28.

18. Konishi J, Yamazaki K, Azuma M, Kinoshita I, Dosaka-Akita H, Nishimura M. B7-H1 expression on non-small cell lung cancer cells and its relationship with tumor-infiltrating lymphocytes and their PD-1 expression. Clin Cancer Res. 2004;10:5094-100.

19. Powles T, Eder JP, Fine GD, Braiteh FS, Loriot Y, Cruz C, Bellmunt J, Burris HA, Petrylak DP, Teng SL, Shen X, Boyd Z, Hegde PS, Chen DS, Vogelzang NJ. MPDL3280A (anti-PD-L1) treatment leads to clinical activity in metastatic bladder cancer. Nature. 2014;515:558-62.

20. Thierauf J, Veit JA, Affolter A, Bergmann C, Grunow J, Laban S, Lennerz JK, Grunmuller L, Mauch C, Plinkert PK, Hess J, Hoffmann TK. Identification and clinical relevance of PD-L1 expression in primary mucosal malignant melanoma of the head and neck. Melanoma Res. 2015;25:503-9.

21. Hamanishi J, Mandai M, Iwasaki M, Okazaki T, Tanaka Y, Yamaguchi K, Higuchi T, Yagi H, Takakura K, Minato N, Honjo T, Fujii S. Programmed cell death 1 ligand 1 and tumor-infiltrating CD8+Tlymphocytes are prognostic factors of human ovarian cancer. Proc Natl Acad Sci USA. 2007;104:3360-5.

22. Ali HR, Glont SE, Blows FM, Provenzano E, Dawson SJ, Liu B, Hiller L, Dunn J, Poole CJ, Bowden S, Earl HM, Pharoah PD, Caldas C. PD-L1 protein expression in breast cancer is rare, enriched in basal-like tumours and associated with infiltrating lymphocytes. Ann Oncol. 2015;26:1488-93.

23. Park IH, Kong SY, Ro JY, Kwon Y, Kang JH, Mo HJ, Jung SY, Lee S, Lee KS, Kang HS, Lee E, Joo J, Ro J. Prognostic implications of tumor-infiltrating lymphocytes in association with programmed death ligand 1 Expression in early-stage breast cancer. Clin Breast Cancer. 2016;16:51-8.

24. Zhang Y, Morgan R, Chen C, Cai Y, Clark E, Khan WN, Shin SU, Cho HM, Al Bayati A, Pimentel A, Rosenblatt JD. Mammary-tumor-educated B cells acquire LAP/TGF- $\beta$ and PD-L1 expression and suppress anti-tumor immune responses. Int Immunol. 2016; pii:dxw007. (Epub ahead of print).

25. Meniawy TM, Lake RA, McDonnell AM, Millward MJ, Nowak AK. PD-L1 on peripheral blood T lymphocytes is prognostic in patients with non-small cell lung cancer (NSCLC) treated with EGFR inhibitors. Lung Cancer. 2016;93:9-16.

26. Topalian SL, Hodi FS, Brahmer JR, Gettinger SN, Smith DC, McDermott DF, Powderly JD, Carvajal RD, Sosman JA, Atkins MB, Leming PD, Spigel DR, Antonia SJ, Horn L, Drake CG, Pardoll DM, Chen L, Sharfman WH, Anders RA, Taube JM, McMiller TL, Xu H, Korman AJ, Jure-Kunkel M, Agrawal S, McDonald D, Kollia GD, Gupta A, Wigginton JM, Sznol M. Safety, activity, and immune correlates of anti-PD-1 antibody in cancer. N Engl J Med. 2012;366:2443-54.

27. Brahmer JR, Drake CG, Wollner I, Powderly JD, Picus J, Sharfman WH, Stankevich E, Pons A, Salay TM, McMiller TL, Gilson MM, Wang C, Selby M, Taube JM, Anders R, Chen L, Korman AJ, Pardoll DM, Lowy I, Topalian SL. Phase I study of single-agent anti-programmed death-1 (MDX-1106) in refractory solid tumors: safety, clinical activity, pharmacodynamics, and immunologic correlates. J Clin Oncol. 2010;28:3167-75.

28. Taube JM, Klein A, Brahmer JR, Xu H, Pan X, Kim JH, Chen L, Pardoll DM, Topalian SL, Anders RA. Association of PD-1, PD-1 ligands, and other features of the tumor immune microenvironment with response to antiPD-1 therapy. Clin Cancer Res. 2014;20:5064-74.

29. Brahmer JR, Tykodi SS, Chow LQ, Hwu WJ, Topalian SL, Hwu P, Drake CG, Camacho LH, Kauh J, Odunsi K, Pitot HC, Hamid O, Bhatia S, Martins R, Eaton K, Chen S, Salay TM, Alaparthy S, Grosso JF, Korman AJ, Parker SM, Agrawal S, Goldberg SM, Pardoll DM, Gupta A, Wigginton JM. Safety and activity of anti-PD-L1 antibody in patients with advanced cancer. N Engl J Med. 2012;366:2455-65.

30. Weber JS, Kudchadkar RR, Yu B, Gallenstein D, Horak CE, Inzunza HD, Zhao X, Martinez AJ, Wang W, Gibney G, Kroeger J, Eysmans C, Sarnaik AA, Chen YA. Safety, efficacy, and biomarkers of nivolumab with vaccine in ipilimumab-refractory or -naive melanoma. J Clin Oncol. 2013;31:4311-8.
31. Tumeh PC, Harview CL, Yearley JH, Shintaku IP, Taylor EJ, Robert L, Chmielowski B, Spasic M, Henry G, Ciobanu V, West AN, Carmona M, Kivork C, Seja E, Cherry G, Gutierrez AJ, Grogan TR, Mateus C, Tomasic G, Glaspy JA, Emerson RO, Robins H, Pierce RH, Elashoff DA, Robert C, Ribas A. PD-1 blockade induces responses by inhibiting adaptive immune resistance. Nature. 2014;515:568-71.

32. Cedres S, Ponce-Aix S, Zugazagoitia J, Sansano I, Enguita A, NavarroMendivil A, Martinez-Marti A, Martinez P, Felip E. Analysis of expression of programmed cell death 1 ligand 1 (PD-L1) in malignant pleural mesothelioma (MPM). PLoS One. 2015;10:e0121071.

33. McLaughlin J, Han G, Schalper KA, Carvajal-Hausdorf D, Pelakanou V, Rehman J, Velcheti V, Herbst R, LoRusso P, Rimm DL. Quantitative assessment of the heterogeneity of PD-L1 expression in non-small-cell lung cancer. JAMA Oncol. 2016;2(1):46-54. doi:10.1001/jamaoncol.2015.3638.

34. Hammond ME, Hayes DF, Dowsett M, Allred DC, Hagerty KL, Badve S, Fitzgibbons PL, Francis G, Goldstein NS, Hayes M, Hicks DG, Lester S, Love R, Mangu PB, McShane L, Miller K, Osborne CK, Paik S, Perlmutter J, Rhodes A, Sasano H, Schwartz JN, Sweep FC, Taube S, Torlakovic EE, Valenstein P, Viale G, Visscher D, Wheeler T, Williams RB, Wittliff JL, Wolff AC. American Society of Clinical Oncology/College Of American Pathologists guideline recommendations for immunohistochemical testing of estrogen and progesterone receptors in breast cancer. J Clin Oncol. 2010;28:2784-95.

35. Wolff AC, Hammond ME, Schwartz JN, Hagerty KL, Allred DC, Cote RJ, Dowsett M, Fitzgibbons PL, Hanna WM, Langer A, McShane LM, Paik S, Pegram MD, Perez EA, Press MF, Rhodes A, Sturgeon C, Taube SE, Tubbs $\mathrm{R}$, Vance $\mathrm{GH}$, van de Vijver M, Wheeler TM, Hayes DF. American Society of Clinical Oncology/College of American Pathologists guideline recommendations for human epidermal growth factor receptor 2 testing in breast cancer. J Clin Oncol. 2007;25:118-45.

36. Elston CW, Ellis IO. Pathological prognostic factors in breast cancer. I. The value of histological grade in breast cancer: experience from a large study with long-term follow-up. Histopathology. 1991;19:403-10.

37. Ahn S, Cho J, Sung J, Lee JE, Nam SJ, Kim KM, Cho EY. The prognostic significance of tumor-associated stroma in invasive breast carcinoma. Tumour Biol. 2012;33:1573-80.

38. Hodi FS, Sznol M, Kluger HM, McDermott DF, Carvajal RD, Lawrence DP, Topalian SL, Atkins MB, Powderly JD, Sharfman WH, Puzanov I, Smith DC, Leming PD, Lipson EJ, Taube JM, Anders R, Horak CE, Kollia G, Gupta AK, Sosman JA. Long-term survival of ipilimumab-naive patients (pts) with advanced melanoma (MEL) treated with nivolumab (anti-PD-1, BMS936558, ONO-4538) in a phase I trial. J Clin Oncol. 2014;32:9002.

39. Teixido C, Karachaliou N, Gonzalez-Cao M, Morales-Espinosa D, Rosell R. Assays for predicting and monitoring responses to lung cancer immunotherapy. Cancer Biol Med. 2015;12:87-95.

40. Patel SP, Kurzrock R. PD-L1 expression as a predictive biomarker in cancer immunotherapy. Mol Cancer Ther. 2015;14:847-56.

41. Rimm D, Schalper K, Pusztai L. Unvalidated antibodies and misleading results. Breast Cancer Res Treat. 2014;147:457-8.

42. Gettinger SN, Shepherd FA, Antonia SJ, Brahmer JR, Chow LQM, Juergens RA, Borghaei H, Shen Y, Harbison C, Alaparthy S, Chen AC, Rizvi NA. First-line nivolumab (anti-PD-1; BMS-936558, ONO-4538) monotherapy in advanced NSCLC: safety, efficacy, and correlation of outcomes with PD-L1 status. J Clin Oncol. 2014;32:8024.

43. Marti AM, Martinez P, Navarro A, Cedres S, Murtra-Garrell N, Salva F. Concordance of PD-L1 expression by different immunohistochemistry (IHC) definitions and in situ hybridization (ISH) in squamous cell carcinoma (SCC) of the lung. J Clin Oncol. 2014;32:7569.

44. Mittendorf EA, Philips AV, Meric-Bernstam F, Qiao N, Wu Y, Harrington S, Su X, Wang Y, Gonzalez-Angulo AM, Akcakanat A, Chawla A, Curran M, Hwu P, Sharma P, Litton JK, Molldrem JJ, Alatrash G. PD-L1 expression in triple-negative breast cancer. Cancer Immunol Res. 2014:2:361-70.

45. Beckers RK, Selinger CI, Vilain R, Madore J, Wilmott JS, Harvey K, Holliday A, Cooper CL, Robbins E, Gillett D, Kennedy CW, Gluch L, Carmalt H, Mak C, Warrier S, Gee HE, Chan C, McLean A, Walker E, McNeil CM, Beith JM, Swarbrick A, Scolyer RA, O'Toole SA. PDL1 expression in triple-negative breast cancer is associated with tumour-infiltrating lymphocytes and improved outcome. Histopathology. 2015. doi:10.1111/his.12904.

46. Sharpe AH, Wherry EJ, Ahmed R, Freeman GJ. The function of programmed cell death 1 and its ligands in regulating autoimmunity and infection. Nat Immunol. 2007;8:239-45. 
47. Taube JM, Anders RA, Young GD, Xu H, Sharma R, McMiller TL, Chen S, Klein AP, Pardoll DM, Topalian SL, Chen L. Colocalization of inflammatory response with B7-h1 expression in human melanocytic lesions supports an adaptive resistance mechanism of immune escape. Sci Transl Med. 2012;4:ra137127.

48. McLaughlin J, Han G, Schalper KA, Carvajal-Hausdorf D, Pelekanou V, Rehman J, Velcheti V, Herbst R, LoRusso P, Rimm DL. Quantitative assessment of the heterogeneity of PD-L1 expression in non-small-cell lung cancer. JAMA Oncol. 2016;2:46-54.

49. Schats K, Vre Ev, Schepper SD, Neyns B, Meester ID, Kockx M. PD-L1 IHC validation and comparison of E1L3N \& SP142 mAbs in melanoma. In: Cancer immunology and immunotherapy melanoma and other skin tumors. ESMO symposium on immuno-oncology 2015: welcome reception and general poster viewing; 2015 .

50. Baker AF, Dragovich T, Ihle NT, Williams R, Fenoglio-Preiser C, Powis G. Stability of phosphoprotein as a biological marker of tumor signaling. Clin Cancer Res. 2005;11:4338-40.

51. Schalper KA, Velcheti V, Carvajal D, Wimberly H, Brown J, Pusztai L, Rimm DL. In situ tumor PD-L1 mRNA expression is associated with increased TILs and better outcome in breast carcinomas. Clin Cancer Res. 2014;20:2773-82.

52. Velcheti V, Schalper KA, Carvajal DE, Anagnostou VK, Syrigos KN, Sznol M, Herbst RS, Gettinger SN, Chen L, Rimm DL. Programmed death ligand-1 expression in non-small cell lung cancer. Lab Invest. 2014;94:107-16.

53. Droeser RA, Hirt C, Viehl CT, Frey DM, Nebiker C, Huber $X$, Zlobec I, Eppenberger-Castori S, Tzankov A, Rosso R, Zuber M, Muraro MG, Amicarella F, Cremonesi E, Heberer M, lezzi G, Lugli A, Terracciano L, Sconocchia G, Oertli D, Spagnoli GC, Tornillo L. Clinical impact of programmed cell death ligand 1 expression in colorectal cancer. Eur J Cancer. 2013:49:2233-42.

54. Mu CY, Huang JA, Chen Y, Chen C, Zhang XG. High expression of PD-L1 in lung cancer may contribute to poor prognosis and tumor cells immune escape through suppressing tumor infiltrating dendritic cells maturation. Med Oncol. 2011;28:682-8.

55. Thompson RH, Gillett MD, Cheville JC, Lohse CM, Dong H, Webster WS, Krejci KG, Lobo JR, Sengupta S, Chen L, Zincke H, Blute ML, Strome SE, Leibovich BC, Kwon ED. Costimulatory B7-H1 in renal cell carcinoma patients: indicator of tumor aggressiveness and potential therapeutic target. Proc Natl Acad Sci USA. 2004;101:17174-9.
56. Adams S, Gray RJ, Demaria S, Goldstein L, Perez EA, Shulman LN, Martino S, Wang M, Jones VE, Saphner TJ, Wolff AC, Wood WC, Davidson NE, Sledge GW, Sparano JA, Badve SS. Prognostic value of tumor-infiltrating lymphocytes in triple-negative breast cancers from two phase III randomized adjuvant breast cancer trials: ECOG 2197 and ECOG 1199. J Clin Oncol. 2014;32:2959-66.

57. Loi S. Host antitumor immunity plays a role in the survival of patients with newly diagnosed triple-negative breast cancer. J Clin Oncol. 2014;32:2935-7.

58. Borghaei H, Paz-Ares L, Horn L, Spigel DR, Steins M, Ready NE, Chow LQ, Vokes EE, Felip E, Holgado E, Barlesi F, Kohlhaufl M, Arrieta O, Burgio MA, Fayette J, Lena H, Poddubskaya E, Gerber DE, Gettinger SN, Rudin CM, Rizvi N, Crino L, Blumenschein GR Jr, Antonia SJ, Dorange C, Harbison $\mathrm{CT}$, Graf Finckenstein F, Brahmer JR. Nivolumab versus docetaxel in advanced nonsquamous non-small-cell lung cancer. N Engl J Med. 2015;373:1627-39.

59. Brahmer J, Reckamp KL, Baas P, Crino L, Eberhardt WE, Poddubskaya E, Antonia S, Pluzanski A, Vokes EE, Holgado E, Waterhouse D, Ready N, Gainor J, Aren Frontera O, Havel L, Steins M, Garassino MC, Aerts JG, Domine M, Paz-Ares L, Reck M, Baudelet C, Harbison CT, Lestini B, Spigel DR. Nivolumab versus docetaxel in advanced squamous-cell non-smallcell lung cancer. N Engl J Med. 2015;373:123-35.

60. Larkin J, Chiarion-Sileni V, Gonzalez R, Grob JJ, Cowey CL, Lao CD, Schadendorf D, Dummer R, Smylie M, Rutkowski P, Ferrucci PF, Hill A, Wagstaff J, Carlino MS, Haanen JB, Maio M, Marquez-Rodas I, McArthur GA, Ascierto PA, Long GV, Callahan MK, Postow MA, Grossmann K, Sznol M, Dreno B, Bastholt L, Yang A, Rollin LM, Horak C, Hodi FS, Wolchok JD. Combined nivolumab and ipilimumab or monotherapy in untreated melanoma. N Engl J Med. 2015;373:23-34.

61. Nanda R, Chow LQ, Dees EC. Abstract s1-09: a phase 1B study of pembrolizumab (MK-3475) in patients with advanced triple-negative breast cancer. In: San Antonio breast cancer symphosium (SABCS), San Antonio. 2014.

62. Emens LA, Braiteh FS, Cassier P: Abstract PD1-6: inhibition of PD-L1 by mpdl3280a leads to clinical activity in patients with metastatic triplenegative breast cancer. In: San Antonio breast cancer symphosium (SABCS), San Antonio. 2014.

63. Gulbahce HE, Gamez R, Dvorak L, Forster C, Varghese L. Concordance between tissue microarray and whole-section estrogen receptor expression and intratumoral heterogeneity. Appl Immunohistochem Mol Morphol. 2012;20:340-3.

\section{Submit your next manuscript to BioMed Central and we will help you at every step:}

- We accept pre-submission inquiries

- Our selector tool helps you to find the most relevant journal

- We provide round the clock customer support

- Convenient online submission

- Thorough peer review

- Inclusion in PubMed and all major indexing services

- Maximum visibility for your research

Submit your manuscript at www.biomedcentral.com/submit 